\title{
Improving College English Teaching Pattern and English Learning Effect among Students in Physical Education Institutes---A Survey on the Implementation of New Concept Teaching Pattern
}

\author{
Youming Wang \\ Foreign Language Teaching Section, Capital Institute of Physical Education, Beijing 100088, China \\ E-mail: wangyouming@cipe.net.cn
}

\begin{abstract}
In order to sharpen English learning capabilities of students in the institutes of physical education, the author makes a tracking investigation of New Concept English teaching model in Grade 08 of the department of sports training and national traditional sports. By analyzing and comparing the students' English levels before and after the experiment, the author comes to the conclusion that the students' interest in learning English has something to do with the teaching materials and teaching patterns. The paper also further suggests that EFL teachers should make suitable teaching patterns in accordance with students' preference so as to promote the development of teaching and learning.
\end{abstract}

Keywords: New Concept teaching model, Interest, Affection, Recitation, Language input-output

For a quite long term, physical education institutes haven't attached enough importance to college English due to their special features. Therefore, compared with their professional courses, college English stands at the edge. With increasing international communications, physical education students are expected to have higher English capacity. In reality, physical education students are largely laggard behind in English compared with those in other majors, especially students in the sports department and the national traditional sports department. In order to improve students' English capacity, the author attempted to employ New Concept teaching pattern among the students in the two departments and had an investigation on its implementation.

\section{Basic Condition}

\subsection{Purpose, Method and Object of the Investigation}

In order to test the influences of New Concept teaching pattern on the learning effects among the sports department and the national traditional sports department, we had an investigation on 211 students from Grade 2008 of the sports department and the national traditional sports department. This investigation was done in two steps: the first one was made one month after students' entry into university in which 211 questionnaires were returned; the second was made after the implementation of the new teaching pattern in which 210 papers were returned. In addition, interviews were held randomly with students after the second investigation to learn about their current difficulties in learning as well as their advice on the new teaching pattern.

\subsection{Content of the Questionnaire and Result}

\subsubsection{The First Investigation}

The first investigation on freshmen mainly involves their learning condition, learning interest, materials and teaching patterns. It is shown that a majority of students have had English learning experience for 6 years or even longer. But there are still a small number of students who have only 3 to 4 years' learning experience. As a result, their English basis varies.

In their recitation and application of oral English, some students can memorize the texts they have learnt in class, most can do that within a week while only a few ones cannot do that, revealing quite great potential in reciting texts. Seen from the frequency of using oral English, $62.14 \%$ of the investigated students don't speak English at all, showing that they fail to apply the texts they have recited and the language materials they have collected in real life and therefore their oral English needs to be improved.

As for learning interest, it is shown that $48.44 \%$ of the investigated students enjoying reading texts aloud while only $8.44 \%$ of them like reciting them. Even the proportion in writing, another channel for language output, exceeds that in reciting. With students' learning condition in which oral English taken into consideration, it shows that these students only read and listen passively instead of beating their brains to memorize and say something.

In terms of the content of oral test, the investigation shows that most students like giving a brief retelling of texts or reciting texts. Some other flexible forms such as improvisation and story telling reveal students' great 
expectations for interesting things. In addition, the interestedness of teaching content takes up the largest proportion (49.55\%) among all the factors influencing students' learning interest, which is well higher than that of teachers' teaching methods, teaching means and teacher-student relationships.

As for teaching materials and teaching methods, among the several textbooks used in our school currently, $57.35 \%$ of the investigated students prefer Book 2 of New Concept English, which is higher than that for Sub-Band College English (I, II) and Experiencing English. In the selection of teaching patterns, funny stories and pictures attract $30.24 \%$ students' attention; second comes group discussion and PPT teaching. Fewer students like the traditional method in which teachers convey information in a one-way form and raise questions. Many students feel like try New Concept teaching pattern.

\subsubsection{The Second Investigation}

This questionnaire mainly focuses on learning interest, learning methods and forms of test, with an emphasis on the comparison before and after the adoption of New Concept teaching pattern.

\section{(1) The Comparison in Interest}

It is shown in the investigation that $39.52 \%$ of students believe the new pattern has positive effect on learning interest and $36.19 \%$ agree that it has positive effect on the class participation degree. However, diversified acceptance of New Concept teaching pattern also exists, which shows that not every student can be adapted to it on one hand and students' diversified learning levels also restrict it from achieving the ideal state.

(2) The Comparison in Learning Methods

Over half of the students think that New Concept teaching pattern promotes students' understanding on texts. After using this method, students have apparently reduced difficulties in reciting texts and less time for that and have strengthened abilities in text retelling and memorization.

In addition, this new pattern has also changed students' methods of text recitation. $46.72 \%$ of the students take advantage of the scene to memorize a text and $22.71 \%$ use the cartoons available in textbooks to memorize a text while only a small number of students use the traditional semantic memorization pattern. Obviously, the scene and graphic teaching emphasized in New Concept teaching pattern helps students to form deep impression of the content of texts.

\section{(3) The Comparison in Test Methods}

It can be shown in the table that there is no obvious change in students' selection of the methods of oral test before and after the application of New Concept teaching pattern. Over half of the students choose to retell texts and many prefer to tell stories and jokes while only a small number of students choose story narration which calls more for a flexible application of language ability. As is revealed, after using the new pattern, students still depend a lot on textbooks and their abilities and wills in practical language use need to be improved.

(4) Random Interviews

In addition to questionnaire investigations on students, we also conducted random interviews among students, in which they revealed the following problems:

Subjectively, students are lacking in enthusiasm and consistency in learning. Most students depend on temporary memory and only a few of them turn to revision on a long term, not to mention applying what they have recited and memorized to practice. In addition, they are lacking in a grasp over basic knowledge and grammar, a large vocabulary as well as basic phonetic knowledge but they are still reluctant to spend more time in improving themselves. They have no lasting enthusiasm and activity for English, hence suffering from temporality and speculativeness.

Objectively, due to the shortage of corresponding language environments and opportunities to use them, students' enthusiasm for relearning and spontaneous application

Students give the following advice on the improvement of teaching patterns during the interview:

First, more class organizations should be organized to offer students more opportunities to practice their oral English.

Second, the introduction to cultural background information should be enhanced and the content of texts should be extended to intrigue learning passion and deepen learning impression.

Third, the explanation of texts should be fuller and more intensive, especially grammar and sentence patterns. Trainings on Band Four Test and writing should also be strengthened.

Fourth, pictures, flashes or songs can be added to provide diversified channels for English learning. 
Fifth, individual teaching should be conducted on students with different basis.

\section{The Analysis on Changes after the Adoption of New Concept Teaching Pattern}

It can be shown in the result of our investigation that positive changes are displayed among most students in their learning interest, learning methods and learning effect. If the causes are explored, there are subjective and objective factors.

\subsection{Subjective Factors}

In his summary of foreign language teaching experience, Krashen points out that emotional factors, including learners' motivation, attitudes, confidence and anxiety and so on, restrain the pace and effect of learning. Therefore, there are close relations among learning interest, motivation, attitudes and effects.

Under the traditional staged teaching pattern, most physical education students tend to lose their learning interest with the increased difficulty due to their poor basic knowledge in grammar, vocabulary and phonetic knowledge. However, New Concept English textbooks and New Concept teaching pattern help to reduce students' disadvantages in their basic knowledge due to the weakened grammar knowledge. Meanwhile, the interest of teaching materials also appeals to students and help them to develop their interest in learning and applying English.

Students in the department of sports and the department of traditional sports have lively characters, which make it easier to stimulate their passion in interactive and situational class activities. The learning pattern of group coordination helps to improve students' learning passion and enhance their subjectivity. Besides, some preferable spirits such as perseverance, no fear for hardships and courage to challenges cultivated in their physical education trainings can be stimulated in activities and applied to English learning so as to yield twice the result with half the efforts.

\subsection{Objective Factors}

In addition to students' own reasons, some exterior factors such as teaching materials, teaching patterns and teaching methods also affect students' learning effect.

(1) Teaching Materials and Teaching Pattern

Most texts in college English textbooks are quite long and its content falls departed from students' reality, hence discouraging students. In New Concept English, rich and interesting contents are provided, which presses close to real life. In addition, every text is equipped with exercises in listening, speaking, reading and writing to improve students' skills in English employment, hence helping to transfer the focus of language teaching from delivering language knowledge to the actual application of language.

The situational, audio lingual and interactive teaching methods are employed in the teaching process. First, situations are introduced to help students to have a pre-familiarity with the passages or dialogues they are to read and questions can be raised to help students to understand the passages better. Then passages should be explained in detail after which students are expected to read the passages to themselves to understand the meaning of sentences, to have oral practice on key sentences and finish the retelling based on some key words. Finally students grasp their knowledge during the speaking and doing process in group discussion. This kind of active teaching pattern can attract students' attention more easily and give them deep impression of the teaching content.

\section{(2) Teachers' Teaching Pattern}

In the traditional teaching method, teachers and teaching materials take the dominance while students are passive recipients, hence lacking in humanity. In New Concept English, there are not only dialogues, compositions and language guided by teachers but also the space for students to express their own advice and opinions. At such class, the teacher is no longer a dominator but an equal participant to have mutual learning with students, which also conforms to English Course Requirements for Non-English Majors (Trial) (the Department of Higher Education of the Ministry of Education, 2004) in which it is laid down that the English teaching pattern should be converted into one centering on students, conveying general language knowledge and skills as well as cultivating language application ability and sell-learning ability.

With the extensive use of network and multi-media, PPT is widely used by teachers in their teaching process, which makes it possible to fully absorb many materials related to the texts from the Internet and to display them in pictures, audio and visual forms, hence enriching teacher's teaching and improving its interest. Particularly, the humorous texts in New Concept English and flexible setting of modules in textbooks are more beneficial for teachers to exert their diversified teaching methods.

It is shown in the above analysis that New Concept English textbooks, teaching patterns, teaching methods have 
conformed to students' interest and demands to some degree. As a result, these objective exterior factors stimulate the changes in students' learning interest, attitudes and therefore improve the learning effect.

\section{Enlightenment and Suggestion}

It has been found out from our survey and analysis that New Concept teaching pattern can improve students' learning interest and effect to some degree, hence popular with students. As a result, this teaching pattern can be spread to other departments of Physical Education Institutes. The following is some advice given by the author on the specific implementation of this teaching pattern:

First, more emphasis should be attached to guiding and stimulating students' learning interest. Proper methods should be employed in dealing with textbooks to attract students' enthusiasm for learning and to stimulate the improvement of their internal motivation for learning.

Second, more efforts should be made in reading aloud and reciting in addition to increasing language input to cultivate students' sensitivity to English phonetics and effective reciting strategies.

Third, language output also needs to be increased based on understandable input to solidify the learnt knowledge. Role plays can be organized according to the textbook content, through which knowledge can be internalized and the application ability of oral English can be improved, hence achieving the goal of dealing with oral communication in real life.

\section{References}

Diane Larsen-Freeman, Michael H. Long. (2000). An Introduction to Second Language Acquisition Research. Foreign Language Teaching and Research Press.

Ding, Haiyan. (2003). The Influence of Krashen Emotional Filtration Hypothesis on Adults' English Acquisition. Journal of Jiangnan University (Social Science). 5.

Krashen, S. (1981). Second Language Acquisition and Second Language Learning. Oxford: Pergamon.

Meng, Fanshao. (2009). A Research on Preventive Strategies Related to Class Silence under the Instruction of Constructivism Theory. Foreign Teaching. 4.

Sun, Yina. (2002). Attention Called for to the Individual Demands of Society and Learners in Foreign Language Teaching: A Perspective of Oral English Teaching. Educational Development Research. (7-8).

Tricia Hedge. (2000). Teaching and Learning in the Language Classroom. Oxford University Press.

Ur., Penny. (2000). A Course in Language Teaching: Practice and Theory. Beijing: Foreign Language Teaching and Research Press.

Table 1. The comparison in the teaching effect before and after New Concept teaching pattern

\begin{tabular}{|c|c|c|c|c|c|c|c|}
\hline \multirow{4}{*}{$\begin{array}{c}\text { Comp } \\
\text { arison } \\
\text { in } \\
\text { intere } \\
\text { st }\end{array}$} & \multirow{2}{*}{\multicolumn{2}{|c|}{$\begin{array}{l}\text { Interest in English } \\
\text { learning }\end{array}$}} & $\begin{array}{c}\text { More interested than } \\
\text { before }\end{array}$ & \multirow{2}{*}{\multicolumn{2}{|c|}{ The same }} & \multicolumn{2}{|c|}{ Less interested than before } \\
\hline & & & $39.52 \%$ & & & \multicolumn{2}{|l|}{$4.29 \%$} \\
\hline & \multirow{2}{*}{\multicolumn{2}{|c|}{ Participating in class }} & $\begin{array}{l}\text { Actively participating } \\
\text { in learning }\end{array}$ & \multicolumn{2}{|c|}{ The same } & \multicolumn{2}{|c|}{$\begin{array}{c}\text { Not actively participating } \\
\text { In learning }\end{array}$} \\
\hline & & & $36.19 \%$ & \multicolumn{2}{|c|}{$57.62 \%$} & \multicolumn{2}{|c|}{$6.19 \%$} \\
\hline \multirow{7}{*}{$\begin{array}{c}\text { Comp } \\
\text { arison } \\
\text { in } \\
\text { learni } \\
\text { ng } \\
\text { metho } \\
\text { ds }\end{array}$} & \multirow{5}{*}{$\begin{array}{l}\text { The time } \\
\text { spent in } \\
\text { reciting a } \\
\text { text }\end{array}$} & & $\begin{array}{l}\text { Retelling a text in } \\
\text { class }\end{array}$ & \multicolumn{2}{|c|}{ Reciting a text within a week } & \multicolumn{2}{|c|}{ Reciting a text over one week } \\
\hline & & Before the & 50 & \multicolumn{2}{|c|}{55} & \multicolumn{2}{|l|}{6} \\
\hline & & experiment & $45.05 \%$ & \multicolumn{2}{|c|}{$49.55 \%$} & \multicolumn{2}{|l|}{$5.4 \%$} \\
\hline & & After the & 94 & \multicolumn{2}{|c|}{91} & \multicolumn{2}{|l|}{25} \\
\hline & & experiment & $44.76 \%$ & \multicolumn{2}{|c|}{\begin{tabular}{|c|}
$44.33 \%$ \\
\end{tabular}} & \multicolumn{2}{|l|}{$11.90 \%$} \\
\hline & \multirow{2}{*}{\multicolumn{2}{|c|}{$\begin{array}{l}\text { Preferable memorizing } \\
\text { methods }\end{array}$}} & Auditory memory & Visual memory & Episodic memory & Semantic memory & Others \\
\hline & & & $9.17 \%$ & $22.71 \%$ & $46.72 \%$ & $10.04 \%$ & $11.35 \%$ \\
\hline \multirow{3}{*}{$\begin{array}{l}\text { Comp } \\
\text { arison } \\
\text { in test } \\
\text { forms }\end{array}$} & \multirow{3}{*}{$\begin{array}{c}\text { Preferable } \\
\text { methods } \\
\text { for oral } \\
\text { text }\end{array}$} & & Reciting several texts & $\begin{array}{c}\text { Briefly } \\
\text { Retelling } 2 \text { texts }\end{array}$ & Story narration & \multicolumn{2}{|c|}{ Improvisation } \\
\hline & & $\begin{array}{l}\text { Before the } \\
\text { experiment }\end{array}$ & $27.27 \%$ & $28 \%$ & $20.36 \%$ & \multicolumn{2}{|l|}{$24.36 \%$} \\
\hline & & $\begin{array}{l}\text { After the } \\
\text { experiment }\end{array}$ & $28.72 \%$ & $26.95 \%$ & $19.15 \%$ & \multicolumn{2}{|l|}{$25.18 \%$} \\
\hline
\end{tabular}

